\title{
ÉLŐNYELV
}

\section{A nyelvjárások a mai magyar szépirodalomban}

1. Bevezetés. A nyelvtudományban ismert tény, hogy a magyar standard kialakulása előtt beszédben és írásban is nyelvjárásokat használtak, és a nyelvjárások jóval hosszabb múlttal rendelkeznek, mint a standard. Idővel a nyelvjárásokat bizonyos szerepkörökben egyre ritkábban alkalmazták, így például az írott nyelvben a standard vette át a helyüket. SÁNDOR ANNA LANSTYÁK ISTVÁNRA hivatkozva említi, hogy a nem standard nyelvváltozatok is alkalmasak lennének a (jelenleg) csak a standardnak tulajdonított tartalmak kifejezésére (LANSTYÁK 2016: 16; idézi SÁNDOR A. 2019: 84), tehát irodalmi múvek ma is íródhatnának nyelvjárásban.

Jóllehet a magyar írott köznyelv elterjedése óta is megjelentek a nyelvjárások az irodalom nyelvében egyes alkalmazási területeken (például a nyelvjárás elemei a szereplők, helyzetek, a népnyelvi környezet jellemzésére és ábrázolására, illetve stilisztikai eszközökként; 1. erröl KISS 2001: 43-44; BÁRCZI 1961), azonban jelenleg ritka, hogy az egész mü nyelvjárásban íródik, különösen egy magas színvonalú irodalmi müként elismert alkotásnál. Pedig ennek gondolata már korábban is felvetődött. 1961-ben közzétett írásában BÁRCZI GÉZA említi, hogy akkoriban is akadtak írók és nyelvészek is, akik kívánatosnak tartották a nyelvjárások minél nagyobb irodalmi érvényesülését, melyet ő szélsőséges álláspontnak tartott, és azt írása szerint határozott elutasítás is követte (BÁRCZI 1961: 74-75). Az azóta eltelt évtizedekben viszont számos változás történt a magyar nyelvet beszélők életében, és a nyelvhasználatra vonatkozó szemlélet is módosult.

A határon túli magyarok szempontjából is kiemelendő az irodalom nyelve, hiszen ott a nyelvjárási, a regionális és az idegen nyelvi kontaktusokból származó nyelvi elemek sajátos irodalmi nyelvet eredményeznek.

2. Az írásbeliség és a nyelvjárási írásbeliség. Több szempontból is megközelíthetjük a nyelvjárási írásbeliség kérdését. Az alábbiakban összegyüjtöttem néhány gondolatot ezzel a kérdéssel kapcsolatban.

PÉNTEK JÁNOS a nyelvpolitika és a nyelvtervezés hátterében található nyelvi ideológiák szerepét is kiemeli a nyelvjárásokkal kapcsolatban: „nem maga a nyelv szabályozott (főképpen írott) változata szorította háttérbe, és hozta rossz hírbe a nyelvjárásokat, hanem a nyelvi ideológiák. Azok a nyelvi ideológiák, amelyek rendszerint együtt kárhoztatják az országon belüli többnyelvüséget és a nyelven belüli táji sokféleséget, és amelyek úgy láttatják, hogy a dialektusok a nyelv romlott, korcs helyi változatai. Európában erre sok példát lehetne idézni, mindenekelött a franciát, közelünkben a románt. Lenézettség, müveletlenség, iskolázatlanság, helytelen nyelvhasználat - ez társult a nyelvjárási beszédhez, ahhoz, aki nyelvjárásban beszélt” (PÉNTEK 2015: 186; idézi PÉNTEK 2019: 57-58). „Ezek a nyelvi ideológiák nem függetlenek azoktól az ismert kultúraelméletektől, amelyek szerint 
a nép nem produkál, csak reprodukál, a népi kultúra elemei a magas kultúrából származnak, onnan süllyedtek le" (PÉNTEK 2019: 57-58).

Napjainkban a szépirodalmi mủ nyelvének nyelvjárásiassága azért lehet meglepő, mert a nyelvjárási nyelvhasználat ma Magyarországon gyakran lenézett (ezért hátrány), a szépirodalom nyelve pedig a köztudatban általában magas presztízsủ (vö. ÉrtSz. irodalmi a.; SZATHMÁRI 2008): „A hátrányos helyzet a nyelvjárások negatív társadalmi megítéléséből, ún. stigmatizáltságából következik. A nyelvjárási beszédmódhoz ugyanis olyan jegyeket kapcsolt a nyelvközösség tagjainak a mértékadó, befolyásoló hatalommal bíró része a köznyelv alakulásának kezdetétől s kapcsol nagyrészt ma is, őket követve később mások is, amelyek egyértelmüen negatív jegyek: műveletlenség, póriasság, iskolázatlanság, maradiság” (Kiss 2006: 544). A „széles körü társadalmi lenézettség” eredete társítható az írásbeliség megjelenésével is. Az írott nyelv társadalmi tekintélye összekapcsolódott az iskolázottsággal és az iskolázottsághoz kötődő foglalkozásokkal. Azután „az írott nyelv presztízse egyre nőtt: ez a formálódó, egységesülő nyelvváltozat vált a társadalmi előbbre jutás, fölemelkedés, kitörés eszközévé és szimbólumává. S ezzel a folyamattal párhuzamosan alakult ki a nyelvjárások megbélyegződése" (KISS 2012: 55). A városban munkát vállaló falusi fiatalok beszédét ott a köznyelv befolyásolta, majd hazatérésükkel a köznyelv behatolt a nyelvjárási beszélők közösségeibe is, és bizonyos beszédhelyzeteket kezdett elhódítani a nyelvjárásoktól (KISS 2012: 56). A lenézettség egy másik oka a társadalmi különbségekhez kapcsolódik. „A rendi társadalom felülről nézte és lenézte az iskolázatlan pórnépet, szokásaival és beszédmódjával együtt. Mind a műveletlenség, mind a hibás nyelvhasználat mint negatív megítélési jegy elsősorban a nyelvjárásoknak a presztízsváltozat (tudniillik eleinte az irodalmi nyelv, később pedig az írott és beszélt köznyelv) ellenpólusaként való felfogásából következik, s történeti összefüggésben az új kort nagyban formáló »magas kultúra: népi kultúra «ichotómiával magyarázható. A magas kultúra nyelvi letéteményese az irodalmi, illetőleg a köznyelv volt, ma is az, a népi kultúráé pedig a népnyelv, a nyelvjárások" (KISS 2002: 6-7).

BÁRCZI GÉZA 1961-ben közzétett dolgozatában a nyelvjárások irodalmi érvényesülése kapcsán arról ír, hogy „,a népi nyelv tekintélyének megvannak a maga korlátai”, és a „népi nyelv a maga sokféleségében, nyelvjárási változatosságában nem léphet a nyelvjárás fölötti, egységes, nemzetileg egyetemleges irodalmi nyelv helyébe" (BÁRCZI 1961: 74). Azonban írókról és nyelvészekről is beszámolt, akik a nyelvjárások „minél nagyobb, lehetőleg teljes irodalmi érvényesülését kívánatosnak" tartották (BÁRCZI 1961: 74). BÁRCZI úgy vélte, hogy a köznyelv és mellette az irodalmi nyelv az egyetemes magyarság összekötő eleme, amely nélkül az egységes nemzet „apróbb nemzettöredékekre” hullana, és ezek nyelvükben is eltávolodnának egymástól, míg végül „a kölcsönös meg nem értésig fokozott nyelvjárási elkülönülésen át kérlelhetetlenül a különnyelvüségbe" jutnának (BÁRCZI 1961: 75). 2020-ban a PÉNTEK-BENŐ szerzőpáros viszont nem látja beigazolódottnak az írói nyelv regionalitásához füződő aggodalmakat. Írásuk szerint az erdélyi irodalomban a saját nyelvközösség iránti felelösségtudat megnyilvánulása is feltünik, és a nyelvjárás sajátos szerepet kap a kisebbségi irodalomban (PÉNTEK-BENŐ 2020: 104-105). Az írók, költők nyelvükkel is saját közösségüket képviselik az egyes régiókban, a nyelv egyben közös éltető és megtartó elem, „élő nyelvi értéket, nyelvi mintát hordoz” (PÉNTEK-BENÖ 2020: 105-106). 
A kisebb közösséghez tartozás jelentősége kapcsán a nyelvjárási szakirodalomban gyakran Németország és Svájc példáját említik, ahol a köznyelv mellett „nyelvjárásban is íródtak és íródnak prózai és lírai alkotások, hangzanak el a rádióban és a televízióban nyelvjárásban írt darabok, s adnak elő színházakban is olyan színmüveket, amelyeket szerzőik nyelvjárásban írnak" (KISS 2001a: 52; továbbá SZANYI 2019: 439-446; FAZEKAS T. 2019: 167). (Azonban angol nyelvü példa is akad az irodalmi mü nyelvjárásiasságára: Irvine Welsh Trainspotting címú írása.)

3. A nyelvjárások írott változatának kérdése. A meghatározások szerint a magyar nyelvjárásoknak nincs külön írásbeliségük, de nyelvjárási írásbeliség ettől még létezik (KISS 2001a: 43), és az írott köznyelv létrejöttéig csak nyelvjárási írásbeliség volt. A magyar nyelvterületen az írott köznyelv kialakulása után is, és ma is előfordul a nyelvjárási írásbeliség, az adatok szerint ez a népi önéletírásokra, emlékírásokra, különböző célzatú feljegyzésekre jellemző, azonban bizonyos országokban a nyelvjárási szépirodalomnak is nagy hagyománya van, például versek, prózai müvek és színdarabok is keletkeznek nyelvjárásban (KISS 2001a: 43; SZANYI 2019). A magyar nyelvü irodalomban ma különlegesnek számít a teljes egészében nyelvjárásban írott szépirodalmi mü, mint például a szlovákiai Száz Pál Fűje sarjad mezőknek címü, 2017-ben megjelent írása. SZANYI ILDIKÓ kutatásai szerint Svájc német nyelvterületén a nyelvjárás irodalmi müvekben történő használata fellendülésben van, jóllehet ennek inkább a szóbeli változatai. „A tájnyelvi hangoskönyvek aránya mára jelentősen megemelkedett, ezzel párhuzamosan viszont a tájnyelvi líra nyomtatott köteteinek száma jelentősen csökkent. Ez a jelenség a mediális váltás következménye, amelyben háttérbe szorul a hagyományos nyomtatott médium” (SZANYI 2019: 443).

A magyar írott köznyelv kialakulása előtt például Zrínyi Miklós Szigeti veszedelem című mủve, Sylvester János az Újszövetséghez írott verse (ez az első disztichonban írt magyar vers), vagy Mikes Kelemen Törökországi levelek címü munkája is tájnyelvi elemekkel íródott. Tehát az egységes irodalmi nyelv kialakulása előtt is lehetett nyelvjárásban magas színvonalú irodalmi müveket létrehozni. Később például Móricz Zsigmond, Tamási Áron vagy Sütő András is alkalmazta a tájnyelvet írásaiban.

3.1. A nyelvjárási jelenségek leírásához kapcsolódó kérdések. A nyelvjárásokat a köznyelvtől hangtani, alaktani, mondattani jelenségei, továbbá a nyelvjárási szókészlet is megkülönbözteti. A kutatások szerint a „nyelvjárások és a köznyelv, illetőleg az egyes nyelvjárások között a legnagyobb különbségek a szókészletben és a frazeológiában, a legcsekélyebbek pedig a nyelvtan legmagasabb szintjein, a szövegszerkesztésben és a mondattanban vannak. A mindenki számára legnyilvánvalóbb nyelvjárásiasságok a köznyelvben ismeretlen nyelvjárási szavak és fonémák, valamint hangrealizációk (például a kettőshangzók), tehát a tájszavak és a táji kötöttségü hangok” (KISS 2006: 518). A nyelvjárási beszéd lejegyzésére példaként szolgálhat a nyelvészek által gyűjtött (vagy lejegyzett) népmesék szövege. PENAVIN OLGA és kollégái az Újvidéki Egyetem Bölcsészeti Karának Magyar Nyelv és Irodalom Tanszékén népmesekötet kiadásával is foglalkoztak. A népmesék és mondák a tanszéken folyó népnyelvkutatások másodlagos termékei voltak, ezek kiadását a folklórkutatóknak szánták. Nem változtattak az elmondott anyagon, mert az élöbeszédet akarták visszaadni, viszont a könnyebb olvashatóság kedvéért egyszerüsített hangjelölést alkalmaztak, ezért kihagyták például a kettőshangzókat és a mellékjeleket (PENAVIN 1984: 10). 
Az alábbiakban kiemelek néhány olyan jellegzetességet a hangtan, alaktan és a nyelvjárási szókincs elemeiből, melyek a nyelvjárások írott változatában megjelennének, viszont a magyar standard nyelvben nem használatosak. (A nyelvjárási mondattan és a beszélt nyelv általános jellemzőihez kapcsolódó kérdésekről 1. HEGEDÜs 2001: 362-363.)

3.2. Hangtan. Akadályozza-e, akadályozhatja-e a szépirodalmi művek nyelvjárásban történő leírását, illetve megírását, hogy bizonyos nyelvjárási hangok nincsenek meg a köznyelvben? Például olyan hangtani jelenségek, mint a zárt $e(\ddot{e})$, nyílt $a(\ddot{a})$, vagy a palóc nyelvjárásban beszélt $a(\dot{a})$ és $a ́(\bar{a})$ hangok írásban jelölése. Vagy hogyan oldható meg a kettőshangzók megjelenítése egy általános írott szövegben is, és ez lassítja-e az olvasást és a szöveg megértését. FAZEKAS TIBORC több szerzőt is említ, akik müveikben tájnyelvi elemeket is alkalmaztak, megállapítása szerint ,az olvasói befogadás pedig zavartalan, függetlenül attól, hogy gyerekekről vagy felnőttekről van szó” (FAZEKAS 2019: 170). A nyelvjárásban író Lakatos Demeter verseinek nyomtatott példányaiban is (vö. Lakatos 2003a) megoldották a hangok jelölésére vonatkozó problémát, mert a szövegben nyomon követhetők a nyelvjárásra jellemző hangtani jelenségek. (Erről 1. még SzENTGYÖRGYI 2016: 249; JuHÁsz 1995.)

Egy jellegzetes hangtani jelenség, a zárt $e(\ddot{)})$ jelölésére volt példa a magyar írott nyelvben, de a maiban már nincs meg. „A zárt ë évszázadok óta lényegében csupán a szóbeliségben élő fonéma, használatát a helyi normák határozzák meg, nincsen tehát kodifikálva. Sorsának alakulását lényegében ez a sajátos helyzet határozza meg" (FODOR 2001: 328).

PETREs CsIzMADIA GABRIELla Száz Pál Fűje sarjad mezőknek című írásával kapcsolatban állapította meg, hogy ,,a szöveglejegyzés az adott nyelvjárás standardtól eltérő fonémáinak korlátozott elemszámát - pl. az ötféle e hang csupán háromféle megjelenítését: e, è, ë - alkalmazza”, hogy a „magyarországi standardhoz szokott olvasó” számára megkönnyítse a szövegbefogadási folyamatot (PETRES CSIZMADIA 2018: 31).

A nyelvjárások szupraszegmentális elemei (hangsúly, hanglejtés, beszédtempó-ritmus, szünet) további kutatásokat igényelnek (FODOR 2001: 346-348), azonban PETRES CSIZMADIA GABRIELLA Száz Pál írásából több példát is lejegyzett az élőbeszédszerüségre, a mindennapi beszélt nyelv elemeire, ilyenek például a „,szupraszegmentális eszközök fonémaszintü jelzései: az összetartozó gondolatokat egybeolvasztó, beszédtempót rögzítő szóegybeírások", betűhatár-eltolódások, a szaggatott beszédet imitáló, a levegővételt nagykötőjelekkel felszabdalva jelző elbeszélés rögzítése, a beszédtempó megnyúlása (Petres Csizmadia 2018: 33).

3.3. Alaktan - igei jelezés. A nyelvjárási alaktan keretén belül szótöveket, képzőket, jeleket és ragokat is tárgyalnak. Itt az alábbi nyelvjárási jelenségekre térek ki. A nákolás, suksükölés, szukszükölés megbélyegzett, nem standard nyelvi forma (SÁNDOR K. 2014: 393-398). A nyelvjárásokban viszont van rájuk példa. HEGEDÜs ATTILA adatai szerint a „feltételes mód egyes szám első személyü alanyi ragozású alakja a köznyelvben várnék, néznék. A veláris hangrendü szavak módjele több nyelvjárásunkban (nyugaton, délen, a palócban) az illeszkedett -ná ([én] várnák)”. A -suk/-sük előfordulásáról ezt állapítja meg: ,a nyugati és a közép-dunántúli nyelvjárási régió kivételével minden más területről adatolhatunk” és ,,a székelyben általános nyelvjárási jelenségnek tekinthető” (HEGEDÜs 2001: 356).

SZENTGYÖRGYI RUDOLF a határon túli magyarokkal kapcsolatban ír erről: „A harmadik említendő példa a suksükölés, szukszükölés, csukcsükölés számos nyelvjárási területen, így a Vajdaságban is. A vajdasági gyerekeket nemigen lehet (de miért kellene?) 
megtanítani arra, hogy ne suksüköljenek. Azt gondolom, nagyobb bajt okozunk azzal, ha megpróbáljuk öket nyelvileg »átnevelni«. Ennek eredménye az elbizonytalanodás, a hiperkorrekció természetellenes kényszere, végül pedig a gátlásokkal elegyített nyelvhasználati kavalkád” (SZENTGYÖRGYI 2016: 248).

3.4. A nyelvjárási szókincs. A, ,tájszó olyan (adott nyelvbeli) szó, amely nincs meg az írott és a beszélt köznyelvben, csak egy vagy több nyelvjárásban, s mint ilyen értelemszerüen területi kötöttségü" (HEGEDÜs 2001: 376). Egy nyelvjárásban írott mü esetében felmerülhet, hogy a tájszavak jelentése kikövetkeztethetö-e a szövegösszefüggésből. Erre utal Balla Zsófia (2019), amikor az anyaországi többségi szemléletű nyelvhasználat elutasítja a kisebbségi író archaikus, vagy nyelvjárási szavait, vagy nyelvtani szerkezeteit. Azonban a moldvai magyar költők versei közlésénél például megfigyelhető, hogy szómagyarázatokat csatolnak a versekhez (vö. Lakatos 2003a).

3.5. A nyelvjárások leírásához (helyesírásához?) kapcsolódó felvetések. A magyar írás betüírás, a hangjelölés a célja (NÁDASDY 2006: 907). A nyelvjárások leírásáról KISS JENŐ így ír: „A nyelvjárások mint nyelvi rendszerek ugyanazon általános nyelvi törvények és szabályok szerint szerveződnek és müködnek, ahogy a köznyelv - s ahogy valamenynyi többi nyelvváltozat. Ebböl következőleg a nyelvjárások és a köznyelv leírása között elvi különbség nincsen. Ugyanazok a szempontok alkalmazhatók, ugyanazon módszerek követhetők mind a köznyelvnek, mind a nyelvjárásoknak mint nyelvi rendszereknek a leírásában. Hogy bizonyos dialektológiai leírások mégis eltérnek a köznyelvi leírásoktól, az nem elvi különbségek következménye, hanem a nyelvjárások sajátos helyzetének, illetőleg a köznyelvhez való viszonyának, valamint az informatív tájékoztatás igényének a velejárója" (KISS 2001b: 87). A dialektológiai leírások rendezőelve a köznyelvvel való egyezés és különbség, továbbá ezek a nyelvjárási többletekre fókuszálnak (KISS 2001b: 87).

A nyelvjárási adatok rögzítésére több lehetőség is a rendelkezésünkre áll, de az alábbi szépirodalmi szövegek a nyelvjáráskutatók speciális tudományos célú hangjelölése nélkül is betekintést nyújtanak az adott nyelvjárás jellemzőibe.

Lakatos Demeter Eljött az üsz címü versének első versszaka (Lakatos 2003b): „Jáccodik moszt az üszi szél a szülülevelekvel / Mezünd, mind a kusa a kertekbe a / gyermekekvel. / Forognak a szárig levelek, minden feli járnak, / És azt hiszi az ember moszt, jó kedvikbül táncalnak."

Száz Pál Fűje sarjad mezőknek. Phytolegendárium című könyvében ez az átírás olvasható: „A szőllővenyigékkē is majnem úgy van, mind a fákkó. A meccíssē a nyövekvís és a termís erejinek aggyuk meg a rengyit. A csërësnye a legszëlídebb fa. Azt nem kő meccenyi, csak hannyi, hogy íjjën a maga rengye szërint” (Száz 2017: 45).

Sántha Attila A murányi kutya (székely nyelvészeti detektívtörténet) címủ írásában található az alábbi mondat: „Fiam - mondta apám születésemkor -, a világ legbütürmecebb fajtája a nyelvész, ne sokat szarozz velik, a múltkor es mondom a komának a korcsomába, ne mind zelegorkodj te, met megsirittlek, erre odaszökik a nyelvész, hogy a'mmi, hát e’nne, s olyant vágtam neki, hogy a szeme kiszökött”' (Sántha 2019: 102).

4. A kisebbségi helyzetben élők magyar nyelve. A kisebbségben élők magyar nyelvére azért szükséges külön is kitérni, mivel elöfordul, hogy körükben a magyarországi köznyelv nem érvényesül. Továbbá a magyar nyelv az egyes határon túli közösségekben egyéni jellemzőkkel is rendelkezik, ez pedig a helyi irodalmi alkotásokban is megmutat- 
kozhat. (A szerző és a közönsége azonos regionális nyelvéről írottakkal kapcsolatban 1. SZANYI 2019: 442-443; PÉNTEK-BENŐ 2020: 105-106.) Az alábbiakban azt mutatom be, hogy a kisebbségben élő magyarok nyelvét hogyan jellemzik. „A magyar államhatárokon kívül élő magyarok kivétel nélkül kontaktusváltozatait beszélik nyelvünknek, vagyis az egynyelvű magyarországi magyarok nyelvétől többé-kevésbé eltérő, a két- vagy többnyelvü környezet hatását mutató változatokat beszélnek. Igaz ez azokra is, akik a többségi nyelvet (szlovákot, románt stb.) nem beszélik s nem is értik, mivel az ő magyar anyanyelvükben is vannak szlovák, román stb. hatás következtében keletkezett, s magyarországi magyarban ismeretlen nyelvi elemek és szabályok" (KONTRA 2006: 551; továbbá a kontaktushatást mutató nyelvi elemekről 1. pl. KONTRA 2006: 549-576; LANSTYÁK 2016, 2018).

A kisebbségben élő magyarok magyar nyelvéről (a kontaktusjelenségeken kívül) azt is tudni lehet, hogy nyelvjárásiasabb, archaikusabb, mint az anyaországi magyaroké. „Kisebbségi körülmények között az anyanyelvhasználat lehetőségei a nyelvjárási nyelvhasználat kivételével mind beszükülnek" (KISS 2001c: 193; továbbá SzOTÁK 2019: 450). A nyilvános nyelvhasználati helyzetekben (például a hivatalokban, a munkahelyen, az iskolában) gyakran a többség által beszélt nyelv használatos, a magyar nyelv pedig az úgynevezett informális-familiáris beszédhelyzetekre, tehát csak egy szük területre korlátozódik (KISS 2001a: 47).

MENYHÁRT JÓZSEF a csallóközi-szigetközi nyelvjárás kapcsán állapítja meg a következőket: „A nyelvjárások a beszélők nyelvi szocializációjának szempontjából is elsődlegesek: a vizsgált nyelvjárási beszélőknek - ahogy általában a szlovákiai magyar közösség nagy részének - ez az elsőként elsajátított változata a később megtanult (vagy meg sem tanult szlovákiai) magyar köznyelvvel (és szlovák nyelvvel) szemben; vagyis ez az elsődleges nyelvváltozat, a köznyelv (és a szlovák nyelv) a másodlagos. [...] Ezen túlmenően a nyelvi kompetencia szempontjából is ez az elsődleges nyelvváltozat, hiszen köztudomású, hogy a kisebbségi magyar közösségekben, beleértve a szlovákiai magyarokat is, a nyelvjárás a domináns nyelvváltozat, mivel a nyelvjárást jóval többen ismerik és használják, mint a köznyelvet. Ez azt is jelenti, hogy: 1. a nyelvjárást a felvidéki magyarok feltehetőleg jóval többen használják mindennapi kommunikációjuk során, mint a magyarországi magyarok; 2. Szlovákiában azok a társadalmi rétegek is gyakrabban használják a (magyar) nyelvjárás(uka)t, melyek Magyarországon ritkábban élnek vele (pl. iskolázott városi beszélők); 3. a szlovákiai magyarok olyan nyelvhasználati színtereken is használják a nyelvjárást, ahol Magyarországon vagy egyáltalán nem, vagy jóval ritkábban fordul elő (hivatalokban, iskolákban)” (MENYHÁRT 2016: 173-174). MENYHÁRT arra is kitér, hogy ,a magyar anyanyelvüek egy része nem magyar tannyelvü iskolába járt, s emiatt nem került intézményes keretek között a magyar köznyelvvel kapcsolatba”, továbbá „,a standard széleskörü elterjedése Magyarországon a Trianon utáni időkben történt, s így ez a folyamat a szlovákiai magyarok nyelvhasználatát már kevésbé érintette" (MENYHÁRT 2016: 173-174).

4.1. A határon túli magyarok nyelve és a magyar nyelv oktatása, továbbá a magyarországi írott köznyelv. A magyar köznyelv írott és beszélt formáját a határon túli magyaroknak is közvetítheti például az iskola, viszont kisebbségi körülmények között az anyanyelvi oktatás lehetőségei korlátozottak (KONTRA 2006: 571-573; Kiss 2001c: 193). A szépirodalmi müvek (majdani) megírása és az azokban alkalmazott nyelv szempontjából erre is érdemes kitérni. PÉNTEK JÁNOS a következő helyzetre mutat rá: ,az anyanyelv standard változatának hiánya mintegy „fedetlenül” hagyja a nyelvjárásokat. A köznyelv 
pedig, a helyi köznyelv maga is regionális vonásokat mutat. Mindez megnöveli a nyelvjárási elemek gyakoriságát, súlyát. Ehhez társul aztán az az új regionalitás, amely a nyelvi interferenciából és a kétnyelvüségből ered” (PÉNTEK 1997: 41; idézi KISS 2001c: 194-195).

Az oktatás nyelvével kapcsolatban felvetődik az a probléma, hogy az anyaországi standard gyakran eltér a kisebbségben élő diákok nyelvétől (SZENTGYÖRGYI 2016). A kisebbségi magyar nyelvtanítás kihívásai a 21. század elején címủ tanulmánykötet (VANČOKOZMÁCS szerk. 2014) megvizsgálta a határon túli magyar diákoknak készült magyar nyelvkönyveket, és többek között az alábbi problémára mutat rá: „A nyelvtanoktatás még a 21. században is abból a feltevésből indul ki, hogy egy normát kellene elsajátíttatni. Azonban már az kétséges, hogy egyáltalán mikori normáról beszélünk. Ma, amikor a technika adta lehetőségek miatt a kommunikáció teljes mértékben megváltozott, a norma is sokkal gyorsabban változik, mint akár ötven évvel ezelött. Viszont a nyelvtankönyvek 3040, néha akár 50 évvel ezelőtti normát kérnek számon" (VANČO 2014: 15). A magyar írott köznyelv problémájához kapcsolható SZENTGYÖRGYI RUDOLF gondolata is: „Üdvözlendő törekvés lehet a regionális köznyelviség, az államnyelvi változatok, illetve egyes nyelvjárások (lásd például Lakatos Demeter költészetét) önálló írásbelisége megteremtésének kísérlete" (SZENTGYÖRGYI 2016: 249).

4.2. A határon túli magyar irodalomban megjelenő nyelvjárás. A kisebbségi irodalom nyelvéről FAZEKAS TIBORC állapította meg a következőket: ,,a határainkon túl, az erdélyi, a szlovákiai és a vajdasági köznyelv, az ottani magyar közbeszéd és irodalom is folyamatosan reflektált a régió nyelvének változásaira, számos szövegben, versekben, de még avantgardnak tekintett szövegekben is megtalálhatjuk a helyi kultúra nyelvének sajátosságait. Különösen legnagyobb regionális nyelvi értékünk, az erdélyi néven összefoglalt nyelvváltozatok mutatnak erős vitalitást és éreztetik hatásukat a kultúra magyarországi fórumain és médiumaiban. Ezt a hatást azonban történelmi reflexek okán nem fogadja egyértelmúen és egyenrangú társként a magyarországi nyilvánosság. Súlyos és pontos szavakkal beszélt erről az ambivalens elutasító-befogadó viszonyról, a magyar kiadói gyakorlatban felbukkanó korrektív (az irodalmi köznyelvi formákat erőltető, szinte cenzori) gyakorlatról a Széchenyi Akadémián elhangzott beszédében Balla Zsófia" (FAZEKAS 2019: 170-171). „Az anyaországban viszont az idegenesnek tünő archaikus, vagy nyelvjárási szavakat, nyelvtani szerkezeteket mellőzné az irodalmi közízlés. A kisebbségi író nyelvi törekvésein két hatalom uralkodik egy életen át: egy más nyelvü többségi nemzet megsemmisítő ereje, és az anyaország többségi szemléletü nyelvhasználata. Mért utasítja el, miért nem érzi inkább nyelvi változatosságnak a honi nagyközönség a murok, potyoló, mánus, vineta, csiklint, csicsonka, málnavész szavakat, a tárgyragos rizset, a nem kapom a szemüvegem (nem találom), a szája prémje (ajak), a talpa szíve (közepe) kifejezéseket és hasonlókat? Mert a megértést nem zavarnák. [...] Ha összevetjük Bodor Ádám Erdélyben publikált prózai műveit és ezek magyarországi kiadásait, meglepetéssel tapasztaljuk, hogy a szerkesztő egy-egy erdélyi kifejezést törölt, és azt magyarországi változattal helyettesítette" (kiemelések az eredetiben; Balla 2019). FAZEKAS TIBORC szavai ,,a magyar kiadói gyakorlatban felbukkanó korrektív (az irodalmi köznyelvi formákat eröltető, szinte cenzori) gyakorlat"-ról emlékeztethetnek arra, ami a kiválasztott nyelvi norma elterjesztésénél felvetődött, miszerint a nyomdai korrektorok, a kiadók olvasószerkesztői vagy a tanárok a kiválasztott nyelvi normának megfelelően javítják a szövegeket (SÁNDOR K. 2006: 961). 
Száz Pál már említett, Fűje sarjad mezőknek. Phytolegendárium címü írása a növényvilághoz kapcsolódó szövegtípusok összessége, nyelvét a mátyusföldi nyelvjáráshoz sorolják. A szövegben található nyelvhasználatot PETRES CsizMADIA GABRIELlA vizsgálta. Adatai szerint a nyelvjárási elemek a szöveg minden szintjén megjelennek. A nyelvjárás nemcsak színesíti a nyelvet, hanem jelzi a hovatartozást, és poétikai jelentősége, továbbá hitelesítő funkciója is van (PETRES CSIZMADIA 2018). Emellett a határon túliak nyelvére jellemző kontaktusjelenségek is megjelennek a szövegben, például szlovák kölcsönszavak, de idegen nyelvi szövegbetoldások, tükörfordítások és kódkeveredés is megfigyelhető. Az elbeszélők nyelvekhez és nyelvváltozatokhoz füződő attitűdjei is kifejeződnek a szövegben. „A mátyusföldi nyelvjárást a beszélők alacsonyabb presztízsértékkel látják el, és a normától eltérőnek, »nem normálisnak« minősítik. [...] A kitelepítésre visszaemlékező egyik elbeszélö így fogalmaz: Oszt hijábo, hogy ëgy nyelvet beszitek a anyások is visszacsúfóták a nípet, hogy maradiú beszill, nem magyarul beszél" (PETRES CSIZMADIA 2018: 38-39).

A Kézdivásárhelyen született Sántha Attila írásaiban székely nyelvi sajátosságokat alkalmaz. A tájnyelvi elemek megjelennek a verseiben és prózájában is (részlet az 1945 tavaszán címü írásából): „Aztán elévette Pali bát Márti: / hát nem szégyelli magát, / megguruzsmálta a tehenyt, / métt irigyelte azt tőlünk? / Páli bá csak ungott-mungott, / hogy eiszen a teheny ehezett, / azért nem adott tejet, / s mindent ne fogjanak reá” (Sántha 2019: 12).

A moldvai magyarok köréböl is megjelentek irodalmi alkotások. A Moldvában élö, magyar-román kétnyelvü lakosság nyelvjárási szempontból több csoportra osztható, összefoglalóan csángóknak is nevezik őket, de egy részük odatelepült székelyek leszármazottja (JUHÁSZ 2001: 307). Ennek következményeképp a moldvai magyarok által beszélt nyelvjárásokban is különbségek vannak. Továbbá, a magyarság többi részétől évszázadok óta elszigetelten élnek, ,nem vettek részt sem a nemzetté válás, sem pedig az anyanyelvi standardizálódás folyamatában” (KISS 2001c: 195). Összehasonlítva a többi magyar nyelvjárással, a moldvai magyar nyelvjárásokat lehet a legnagyobb fokú nyelvjárásiassággal jellemezni (KISS 2001c: 195). A kétnyelvűség és a nyelvcsere a mindennapjaik része, a nyelvjárási szókészletet illetően erős a román hatás (KISS 2001c: 199). Ide kapcsolódik, hogy a nyelvváltozatuk sem a misézés, sem az állami oktatás gyakorlatában nem jellemző (KISS 2001c: 195; SÁNDOR 2014: 144-155). „Anyanyelvükön csak kevesen, ritkán és nehézségekkel írnak, s magyar szövegeikben is a román ábécét használják” (KISS 2001c: 198).

HOPPA ENIKÖ az alábbiak szerint foglalta össze a moldvai magyarokra is jellemző problémákat, melyek a nyelvsziget-helyzetben levő közösségek nyelvjárásának írásbeliségét jellemzi. Számukra a saját nyelvük köznyelvi változata nehezen elérhető, a mindennapokban nem használható. A hosszú ideje fennálló elszigeteltség miatt a moldvai magyar nyelvjárások és a magyar köznyelv jelentősen eltér. A moldvai magyarok számára az írott nyelv a többségi nyelv írott változata. (HoPPA 2009: 125.) A moldvai magyarok nyelvéről még nem jelent meg nyelvtankönyv, azonban A moldvai magyar nyelv szótára már elkészült. Az ismeretes nyelvjárási szövegek egyházi énekek, lakodalmi vagy egyéb rigmusok lejegyzései. „A magyar írásrendszer ismerete híján a helybeliek román írásrendszerben rögzítették őket” (KÓs 1994: 284; idézi HoPPA 2009: 125). „A nyelvjárás írott formája emellett egy-egy helyi költő tollából származik, akik a magyar írásrendszerre támaszkodnak. Ilyenek voltak a szabófalvi Lakatos Demeter vagy a klézsei Duma András" (HoPPA 2009: 127). HOPPA ENIKÖ többször járt Moldvában, tapasztalatairól így ír: „Több falu 
általános iskolájában választható tárgy a magyar nyelv, melynek keretében a magyar köznyelvet s annak írott változatát, az irodalmi nyelvváltozatot tanítják. A nyelvjárás annyiban van jelen az órákon, hogy a nyelvjárási jegyeket nem javítják" (HoPPA 2009: 127).

A moldvai magyar közösségekből kikerülő írók, költők tehát akár a magyar, akár a román köznyelvet választják müveik megírására, mindkettő jelentősen eltér a moldvai magyar falvak nyelvjárásától. A moldvai magyar (csángó) írók és költők felsorolását rendszerint Lakatos Demeterrel (1911-1974) kezdik, de utána más alkotók is jöttek a moldvai irodalomban. (L. például a Magyar Napló 2012. májusi számát.) A fentebb említett költő Demeter Lászlóként született Szabófalván, az elemi iskolát románul végezte, majd lakatosnak tanult. Autodidakta költő volt. Verseiben a szabófalvi moldvai magyar nyelvjárást használta (HALÁSz 2009). Másik példa Demse Márton (Somoska, 1943-). Székelyudvarhelyen végzett tanítóképzőt, azután Somoskán tanított, később mozdonyvezető volt, majd Magyarországra települt. ${ }^{1}$ Somoskai tél című írásában a magyar irodalmi nyelvet tájszavakkal gazdagítja (pl. disznópurkeléc, megyán, lifiter, csiskavin, vénica, szányikó, báliga, hiu), hangtani jellegzetességeket is alkalmaz (pl. kútágos, borozdákra, bővölködhettünk, bövön), és az alábbi mondatban a kitámasztjuk köznyelvi forma helyett a kitámasszuk szerepel: „Az ablak alsó részén késsel kifúrjuk a jeget, a lyukan egészen az udvarig madzagot nyújtunk, az udvarra meg egy kis búzát lopunk a hóra, és kitámasszuk a nagy mosóteknőt és lessük, várjuk, hogy a veréb bújjék búzát enni”, de az egész szöveg nem nyelvjárásban íródott (Demse 2007).

5. Záró gondolatok. A nyelvjárások ,teljes értékü és magas kifejezőképességü nyelvi rendszerek" (KISS 2001a: 53), ezért alkalmasak lehetnének például a szépirodalmi művek megírására, azok teljes nyelvére is. Azonban a nyelvjárások visszaszorulásának egyik okaként éppen azt jelölik meg, hogy a köznyelv és annak írott változata magasabb presztízsü a köztudatban. Kérdés azonban, hogy a nyelvjárások presztízsének növekedése nélkül elterjedhetnek-e szélesebb körben a nyelvjárásban írott szépirodalmi művek. Az iskolai oktatás szemlélete is befolyásolja a köznyelv és más nyelvváltozatok használatát, de az irodalom nyelvéről kialakult nézetet is. „A magyar anyanyelvi nevelésben uralkodó kultúraközpontú müveltségképre jellemző, hogy hangsúlyos szerepet kap az irodalmi tájékozottság és anyanyelvi igényesség. A nyelvi kifejezést, az esztétikai befogadást, a morális válaszadást hangsúlyozza, és fő eszközének a kitünő nyelvi és irodalmi példák bemutatását tekinti” (PLETL 2014: 22). A határon túli magyarok egy része viszont nem beszéli a magyarországi köznyelvet, többen nem magyar tannyelvü iskolába jártak, illetve járnak, ezért a magyar köznyelvvel ök ott nem kerülnek kapcsolatba. Emellett a kisebbségben élök körében az is jellemző, hogy a nyelvjárást olyan nyelvhasználati színtereken is használják, ahol Magyarországon egyáltalán nem, vagy jóval ritkábban (MENYHÁRT 2016: 174). Az iskolai oktatás nyelve Magyarországon (is) a köznyelv, de a pedagógusoktól elvárt feladat, hogy a nyelvjárások értékeire is felhívják a diákok figyelmét. A NAT „(expressis verbis) nem írja elő közvetlenül a kötelező köznyelv-elsajátítást. Közvetve azonban kimondatlanul is alapvető követelményként jelenik meg a köznyelv (sztenderd) ismeretének és használatának a kritériuma" (SZENTGYÖRGYI 2016: 244). Magyarországon a nyelvjárások használata megbélyegzett, ezért elöfordulásuk is korlátozott, itt a nyelvjárások jelenleg szinte csak

${ }^{1}$ Vö. https://moly.hu/konyvek/demse-marton-csango-kuzdelem (2020. 05. 26.) 
a családi, informális érintkezés nyelveként elfogadottak, egyéb használati területeken pedig gyakran megbélyegzettek (KISS 2001a: 47). Bár kisebbségi helyzetben jellemzőbb a nyelvjárási nyelvhasználat, de a kutatások szerint a magyarországi iskolákban tanított norma hatása a határon túl is érvényesül (VANČO-KOZMÁCS szerk. 2016). A kisebbségi magyar nyelvtantanítás egyik fontos tapasztalata, hogy miközben minden nyelvnek többféle változata van, a „nyelvtanoktatás a 21. században is abból a feltevésből indul ki, hogy egy normát kellene elsajátíttatni” (VANČO 2014: 15).

A magyar szépirodalom nyelvében a standard kialakulása elött (de azután is) több nyelvjárás elemei is helyet kaptak, jelenleg azonban a nyelvjárási és a standardtól eltérő elemek használata, köztük a helyesírási szabályok megsértése is vitatott (1. erről LANSTYÁK 2018; SÁNDOR K. 2014, 2006: 961; NÁDASDY 2006: 923-930; FAZEKAS T. 2019: 170171; SÁNDOR A. 2019: 100; SzENTGYÖRGYI 2016). A határon túli szerzők szépirodalmi müveiben előfordul, hogy megjelennek a helyi nyelvhasználat elemei, de jóval kevesebb a teljes egészében nyelvjárásban írott alkotás.

A szépirodalmi müvek nyelvének szabad megválasztásáról SIMON ANGÉLA egy szintén alacsony presztízsủ nyelvváltozat, a szleng kapcsán írja az alábbiakat: „A szépirodalmi alkotásokban a nyelvi eszközök változatos funkciót töltenek be, ezáltal lehetővé teszik a nyelv kifejező eszközeinek különleges és rendkívül változatos felhasználási módjait. A mủvészi hatásra való törekvés indokolja a nyelv lehetőségeinek minél szélesebb körü kiaknázását, esetünkben eltérő stílusváltozathoz tartozó szókészlet, illetve kifejezéskészlet átültetését, abban az esetben is, ha eltér a szoros értelemben vett irodalmi nyelvtöl. Az irodalom nyelve önelvü, saját világú, nagymértékben függ az alkotótól és annak müvészi céljaitól, amelynek érdekében a nyelv változatos lehetőségeinek nagymértékü értékesítésére törekedve, az írók és költők kiemelkedő szerepet tölthetnek be az irodalmi nyelv, az irodalmi stílusok gazdagításában, a kifejezési lehetőségek megújításában. Lehetővé téve azt is, hogy a mindennapi, természetes nyelv alkalmassá váljon esztétikai értékü szövegek létrehozására.” (SIMON 2007: 18.)

Kulcsszók: nyelvjárás, nyelvjárási írásbeliség, írott köznyelv, a szépirodalom nyelve, a határon túli magyar nyelv.

\section{Szépirodalmi források}

Balla Zsófia 2019. A vers hazája III. Litera. 2019. január 13. https://litera.hu/irodalom/elso-kozles/ balla-zsofia-a-vers-hazaja-iii.html (2020. 05. 26).

Demse Márton 2007. Somoskai tél. Zelegor Kiadó, Kézdivásárhely.

Lakatos Demeter 2003a. Lakatos Demeter csángó költő. http://mek.oszk.hu/kiallitas/erdelyi/lakatosdemeter.htm (2020. 10. 12.)

Lakatos Demeter 2003b. Csángú országba. Az Összegyüjtött versek, mesék és levelek nyomán. Összeállította: Libisch Győző. Válogatta és a kéziratokat gondozta: Guther M. Ilona. Internetes megjelenés: Cseke Gábor - Andrassew Iván. Lakatos Demeter Csángómagyar Kulturális Egyesület, Budapest. https://mek.oszk.hu/kiallitas/erdelyi/lakindex.htm (2020. 10. 12.).

Sántha Attila 2019. Hogyan menjünk radinába a lërhëz? Kárpát-medencei Tehetséggondozó Nonprofit Kft., Budapest.

Száz Pál 2017. Füje sarjad mezőknek. Phytolegendárium. Kalligram, Dunaszerdahely-Pozsony. 


\section{Hivatkozott irodalom}

BÁRCZI GÉZA 1961. Nyelvjárás és irodalmi stílus. In: Stilisztikai tanulmányok. A Kiadói Főigazgatóság stilisztikai elöadássorozatának teljes anyaga. Gondolat Kiadó, Budapest. 62-115.

BÓDI ZOLTÁN - FERENCZI GÁBOR - PÁL HELÉN szerk. 2019. A magyar nyelvjárások a XXI. században - nyelvstratégiai megközelitésben: Tanulmánykötet a Magyar Nyelvstratégiai Intézet által 2018. december 4-5-én rendezett konferencián elhangzott elöadásokból. Magyarságkutató Intézet, Budapest.

ÉrtSz. = A magyar nyelv értelmező szótára 1-7. Főszerk. BÁRCZI GÉZA - ORSZÁGH LÁsZLó. Akadémiai Kiadó, Budapest, 1959-1962.

FAZEKAS TIBORC 2019. Nyelv és polgárosodás. A társadalom és a kultúra állapotának szerepe nyelvjárásaink visszaszorulásában. In: BóDI-FERENCZI-PÁL szerk. 2019: 153-175.

FODOR KATALIN 2001. A nyelvjárási hangtani jelenségek. In: KISS szerk. 2001: 325-350.

HALÁsZ PÉTER 2009. A pogocsás ember. Müvelödés 62/4: 21-23.

HEGEDÜS ATTILA 2001. A nyelvjárási alaktani jelenségek. In: KISS szerk. 2001: 351-361.

HOPPA ENIKŐ 2009. Nyelvjárás és írásbeliség. In: GECSŐ TAMÁS - SÁRDI CSILLA szerk., A kommunikáció nyelvészeti aspektusai. Tinta Könyvkiadó, Budapest. 123-128.

JuHÁsZ DeZső 1995. Lakatos Demeter a nyelvjárásórán. In: LACZKÓ KRISZTINA szerk., Emlékkönyv Szathmári István hetvenedik születésnapjára. ELTE BTK Mai Magyar Nyelvi Tanszék, Budapest.

JUHÁSZ DEZSŐ 2001. A moldvai nyelvjárási régió. In: KISS szerk. 2001: 307-316.

KIEFER FERENC föszerk. 2006. Magyar nyelv. Akadémiai Kiadó, Budapest.

KISS JENŐ 2001a. Nyelvek, nyelvváltozatok, nyelvjárások. In: KISS szerk. 2001: 23-56.

KISS JENŐ 2001b. A nyelvleírás módszertani kérdései. In: KISS szerk. 2001: 82-91.

KISS JENŐ 2001c. A regionális nyelvhasználat és vizsgálata. In: KISS szerk. 2001: 175-256.

KISS JENÖ szerk. 2001. Magyar dialektológia. Osiris Kiadó, Budapest.

KISS JENŐ 2002. Dialektológia és nyelvtudomány: hagyomány és korszerüség. Magyar Nyelvjárások 40: 3-20.

KISS JENŐ 2006. Nyelvjárások, regionális nyelvváltozatok. In: KIEFER főszerk. 2006: 517-548.

KISS JENÖ 2012. A magyar nyelv és nyelvközösség. Balaton Akadémia, Keszthely.

KONTRA MIKLÓS 2006. A határon túli magyar nyelvváltozatok. In: KIEFER föszerk. 2006: 549-576.

KOZMÁCS ISTVÁN - VANČO ILDIKÓ szerk. 2016. Standard - nem standard. Variációk egy nyelv változataira. Válogatás a 18. Élönyelvi Konferencia-Nyitra, 2014. szeptember 18-20. - elöadásaiból. Antológia Kiadó, Lakitelek.

LANSTYÁK ISTVÁN 2016. Standardizálás. In: KoZMÁCS-VANČO szerk. 2016: 13-28.

LANSTYÁK ISTVÁN 2018. Nyelvalakitás és nyelvi problémák. Gramma Nyelvi Iroda - Fórum Kisebbségkutató Intézet, Somorja.

MENYHÁRT JÓZSEF 2016. Ez tart minket össze, a mi saját kis nyelvünk. Sztenderd és nyelvjárás a Csallóközben. In: KOZMÁCS-VANČO szerk. 2016: 173-188.

NÁDASDY ÁDÁM 2006. Nyelv és írás. In: KIEFER főszerk. 2006: 907-931.

PENAVIN Olga 1984. Jugoszláviai magyar népmesék 1. Akadémiai Kiadó, Budapest.

PÉNTEK JÁNOS 2019. A nyelvjárások többletértéke a külső régiók kettősnyelvüségében és kétnyelvüségében. In: BÓDI-FERENCZI-PÁL szerk. 2019: 51-86.

PÉNTEK JÁNOS - BENŐ ATTILA 2020. A magyar nyelv Romániában (Erdélyben). Szerk. KonTRA MiKLÓs. Erdélyi Múzeum-Egyesület - Gondolat Kiadó, Kolozsvár-Budapest.

Petres CSIZMADIA GABRIELLA 2018. „Hijábo beszíll így vagy úgy a embër, akkor is csak a magájjét mongya." Irodalmi Szemle 61/10: 30-43.

PletL RITA 2014. A nyelvtan státusa a kisebbségi anyanyelvoktatásban. In: VANČO-KozMÁCS szerk. 2014: 17-29. 
SÁNDOR ANNA 2019. A magyar nyelvjárások jelene és jövője Szlovákiában. In: BóDI-FERENCZIPÁL szerk. 2019: 87-110.

SÁNDOR KLÁRA 2006. Nyelvtervezés, nyelvpolitika, nyelvmüvelés. In: KIEFER főszerk. 2006: 958-995.

SÁNDOR KLÁRA 2014. Határtalan nyelv. SZAK Kiadó Kft., Bicske.

SimON ANGÉLA 2007. Szleng és irodalom. Szakdolgozat. Debreceni Egyetem Bölcsészettudományi Kar Magyar Nyelvtudományi Tanszék, Debrecen. http://mnytud.arts.unideb.hu/szakdolgozat/1546/simon_a_1546.pdf (2020.10.12.)

SZANYI ILDIKÓ 2019. „A nyelvjárás az identitásom része, mely megadja számomra az önkifejezés lehetőségét." A dialektushasználat aktuális tendenciái német Svájcban. In: BóDI-FERENCZIPÁL szerk. 2019: 439-446.

SZATHMÁRI ISTVÁN 2008. Az irodalmi nyelv. In: Sipos LAJOS főszerk., Pannon enciklopédia. Magyar nyelv és irodalom. Urbis Könyvkiadó, Budapest. 133-135.

SZENTGYÖRGYI RUDOLF 2016. Államnyelv, nyelvi sztenderd és anyanyelvoktatás. In: KOZMÁCSVANČO szerk. 2016: 243-249.

SzOTÁK SzILVIA 2019. Az őrvidéki magyar nyelv változatai. In: BóDI-FERENCZI-PÁL szerk. 2019: $447-468$.

VANČO ILDIKÓ 2014. A szlovákiai magyar nyelvtantanítás kihívásai. In: VANČO-KOZMÁCS szerk. 2014: 13-16.

VANČO ILDIKÓ - KOZMÁCS ISTVÁN szerk. 2014. A kisebbségi magyar nyelvtantanitás kihívásai a 21. század elején. Univerzita Konštantina Filozofa v Nitre Fakulta Stredoeurópskych Štúdií / Nyitrai Konstantin Filozófus Egyetem Közép-európai Tanulmányok Kara Magyar Nyelv- és Irodalomtudományi Intézet, Nitra/Nyitra.

\section{Dialects in recent Hungarian works of fiction}

Hungarian dialects were used orally and in writing too before the formation of standard language. For this reason, dialectal elements can be found in several literary works, not only prior to the formation of standard language but also after it. Nowadays low prestige is connected with Hungarian dialects, but the written and spoken standard variety has high reputation (KISS 2012: 55). However, Hungarian beyond the state borders usually has more dialectal elements than this language has in the mother country; therefore, in this case the disdain of Hungarian dialects is controversial. From the aspect of Hungarian dialects, we should revise the definition of the language of literary works and that of standard language, too, in school education. Dialectal elements of works of fiction written before the formation of the Hungarian standard language or beyond the state borders are part of the language of Hungarian literature as well.

Keywords: dialect, literacy in dialects, standard language, language of literature, transborder Hungarian language.

PÁL HELÉN 